\title{
ПОКАЗНИКИ ВІЛЬНОРАДИКАЛЬНОГО ОКИСНЕННЯ В ЩУРІВ ЗА УМОВИ “ПАСИВНОГО ТЮТЮНОКУРІННЯ” НА ТЛІ ТРИВАЛОГО ВВЕДЕННЯ ГЛУТАМАТУ НАТРІЮ У СТАТЕВОМУ І ВІКОВОМУ АСПЕКТАХ
}

Вступ. Значна розповсюдженість тютюнокуріння - глобальна проблема людства, на вирішення якої спрямовані зусилля багатьох учених і фрахівців. Водночас відмітною особливістю сучасних харчових технологій є використання харчових добавок. До найпоширеніших харчових добавок як в Україні, так і в Європі належить глутамат натрію (E621), який не завжди безпечний для здоров'я людини.

Мета дослідження - вивчити показники вільнорадикального окиснення в крові та тканині легень щурів за умови “пасивного тютюнокуріння" на тлі тривалого введення глутамату натрію у статевому і віковому аспектах.

Методи дослідження. Досліди проведено на 128 білих нелінійних статевозрілих і статевонезрілих щурах обох статей. Кожну групу тварин було поділено на 4 підгрупи: 1-ша - контроль; 2-га - щури, в яких моделювали “пасивне тютюнокуріння"; 3-тя - щури, яким вводили глутамат натрію; 4-та - щури, в яких моделювали “пасивне тютюнокуріння" на тлі введення глутамату натрію.

Результати й обговорення. За умови “пасивного тютюнокуріння" встановлено виражене зростання вмісту ТБК-активних продуктів як у сироватці крові, так і в гомогенаті тканини легень. У щурів-самців він достовірно збільшився у 3,3 та 4,2 раза відповідно, а в щурів-самок - у 3,9 і 5,2 раза. При тривалому введенні глутамату натрію в самців цей показник достовірно підвищився в 1,6 та 2,1 раза, а в самокна 19,6 і 53, 9 \%. У тварин, в яких моделювали “пасивне тютюнокуріння" та яким вводили глутамат натрію, встановлено найбільш виражене зростання вмісту ТБК-активних продуктів. У щурів-самців даний показник достовірно підвищився в 4,9 та 6,8 раза, а в щурів-самок - у 6,5 і 8,9 раза.

Висновки. За умови “пасивного тютюнокуріння" спостерігають інтенсифікацію пероксидного окиснення ліпідів (підвищення вмісту ТБК-активних продуктів) у крові та тканині легень, більш виражену при "пасивному тютюнокурінні" на тлі введення глутамату натрію. При статевому зіставленні змін показників системи пероксидного окиснення ліпідів виявлено їх достовірне переважання в щурів-самок, при віковому - їх достовірне переважання у статевонезрілих тварин.

КЛЮЧОВІ СЛОВА: тютюнокуріння; глутамат натрію; вільнорадикальне окиснення.

ВСТУП. Значна розповсюдженість тютюнокуріння - глобальна проблема людства, на вирішення якої спрямовані зусилля багатьох учених і фрахівців [1, 2]. Небезпека тютюнокуріння полягає в негативному впливі не лише на стан здоров'я курців, але і на самопочуття осіб, які не курять, проте піддаються шкідливому впливу забруднювачів, що надходять в атмосорерне повітря з тютюновим димом [3]. Численні дослідження, проведені в різних країнах світу, підтвердили зв'язок пасивного куріння зі збільшенням кількості звертань за медичною допомогою та госпіталізацій на 20-30 \% [4].

За даними інорормаційного центру з проблем алкоголю, куріння і наркотиків в Україні, курять (c) А. В. Руцька, І. Я. Криницька, М. І. Марущак, 2017. цигарки 19 млн осіб, вік яких - 15 років і більше (40 \%, 3 них 34 \% курять щодня, 6 \% - час від часу), що є найвищим показником серед країн Європи. За останні 10 років споживання цигарок серед населення зросло в 5 разів. У третини курців стаж куріння становить понад 20 років, у 19 \% - 6-10 років; 37 \% опитаних осіб викурюють 16-20 цигарок за день, 33 \% - 6-10 цигарок. В Україні курить кожен другий чоловік і кожна п'ята жінка. Поширеність куріння серед жінок у 2005 р. становила 20 \% (найвищий показник у країнах СНД). За останні роки кількість курців серед жінок в Україні зросла у 3 рази. Тютюнокуріння є дуже поширеним серед підлітків та дітей, які все більше набувають даної звички, що особливо хвилює оточуючих. Кожна третя дитина віком 12-14 ро- 
ків і кожна друга дитина, старша 15 років, курить цигарки $[5,6]$.

Водночас відмітною особливістю сучасних харчових технологій $є$ використання харчових добавок. До найпоширеніших харчових добавок як в Україні, так і в Європі належить глутамат натрію (E621), який не завжди безпечний для здоров'я людини [7]. На сьогодні немає достовірних даних про те, в яких дозах і за яких умов глутамат натрію, що споживається в їжу постійно у вигляді добавки E621, шкідливий для здоров'я [8]. Існують дослідження про те, що приймання глутамату натрію в кількості 3 г на день $€$ небезпечним для здоров'я людини [9]. Проте деякі вчені стверджують, що щоденне введення щурам глутамату натрію навіть у безпечних для здоров'я людини дозах (15 і 30 мг/кг, що відповідає 1 й 2 г на середньостатистичну людину) протягом 20-ти і 30-ти днів призводило до подразнення слизової оболонки шлунка, що проявлялося розвитком крововиливів, ерозій та виразок, збільшенням базальної секреції соляної кислоти і маси тіла [10].

Дослідження впливу різноманітних шкідливих чинників на інтенсивність процесів пероксидного окиснення ліпідів (ПОЛ) у біологічній системі залишаються актуальними і сьогодні. Під час розвитку патологічних процесів стрімко зростає інтенсивність ліпопероксидації, що робить її універсальним механізмом пошкодження клітинних мембран. Продукти ПОЛ порушують структурну цілісність мембран клітини, їх осмотичну резистентність і електричний потенціал, окиснюють тіолові сполуки і SH-групи білків, порушують структуру нуклеїнових кислот, білків, амінокислот [11].

Тому метою цього дослідження було вивчити показники вільнорадикального окиснення у крові та тканині легень щурів за умови “пасивного тютюнокуріння" на тлі тривалого введення глутамату натрію в статевому та віковому аспектах.

МЕТОДИ ДОСЛІДЖЕННЯ. Досліди проведено на 32 безпородних статевозрілих білих щурах-самцях масою 180-200 г, 32 безпородних статевозрілих білих щурах-самках масою 180200 г, 32 безпородних статевонезрілих білих щурах-самцях масою 60-80 г, 32 безпородних статевонезрілих білих щурах-самках масою 60-80 г, яких утримували на стандартному раціоні віварію.

Кожну групу тварин було поділено на 4 підгрупи: 1-ша - контроль (n=8); 2-га - щури, в яких моделювали "пасивне тютюнокуріння" $(\mathrm{n}=8) ;$ 3-тя - щури, яким вводили глутамат натрію (n=8); 4-та - щури, в яких моделювали “пасивне тютюнокуріння" на тлі введення глутамату натрію $(\mathrm{n}=8)$.

Моделювали “пасивне тютюнокуріння" шляхом поміщення щурів у спеціально сконструйовану камеру з оргскла об'ємом 30 л, в якій розподіляли тютюновий дим. Розрахунок еквівалентної дози нікотину і часу експозиції тварин тютюновим димом проводили на підставі апробованої моделі А. С. Соломіної [12] і розрахунків Л. В. Лізурчик та О. В. Шейди [13]: якщо середньостатистичний курець викурює одну пачку (20 цигарок) на день, то в організм при цьому потрапляє 20 мг нікотину. Тому еквівалентна доза нікотину для щура, від середньої маси людини 70 кг, становитиме 0,043 мг на день. Для проведення експерименту використовували сигарети "Прима срібна (червона)" (смоли - 10 мг/сиг., нікотин - 0,8 мг/сиг.). Піддослідні щури проходили процедуру “пасивного тютюнокуріння" 2 рази на добу. Таким чином, одна тварина в експерименті отримувала максимум 0,048 мг нікотину, що відповідало добовій дозі для людини. Після закінчення кожного 30-хвилинного сеансу тварин витягали з камери і поміщали в стандартну клітку віварію. щурів контрольної групи поміщали в камеру без задимлення 2 рази на добу протягом 30 хв. Тривалість експерименту становила 30 днів.

щурам 2-ї дослідної підгрупи протягом 30-ти днів внутрішньошлунково вводили глутамат натрію в дозі 30 мг/кг, розчинений у 0,5 мл дистильованої води кімнатної температури [14].

У щурів 4-ї дослідної підгрупи моделювали “пасивне тютюнокуріння", і вводили їм глутамат натрію.

Усі маніпуляції з експериментальними тваринами проводили з дотриманням правил відповідно до Європейської конвенції про захист хребетних тварин, що використовуються для дослідних та інших наукових цілей [15].

Для досліджень використовували сироватку крові та гомогенат тканини легень.

У відібраних зразках оцінювали інтенсивність процесів ПОЛ за вмістом вторинних продуктів ліпопероксидації - ТБК-активних продуктів (ТБК-АП) [16].

Статистичну обробку цифррових даних здійснювали за допомогою програмного забезпечення Excel (Microsoft, США) та STATISTICA 6.0 (Statsoft, США) з використанням непараметричних методів оцінки одержаних даних. Для всіх показників розраховували значення середньої арисрметичної вибірки (М), її дисперсії і помилки середньої (m). Достовірність різниці значень між незалежними кількісними величинами визначали за допомогою критерію Манна-Уїтні. Зміни вважали статистично достовірними при $р<0,05$. 
РЕЗУЛЬТАТИЙ ОБГОВОРЕННЯ. РеЗУЛЬТаТИ визначення вмісту ТБК-активних продуктів у сироватці крові та гомогенаті тканини легень статевозрілих контрольних і піддослідних тварин наведено в таблиці 1.

При порівнянні показників пероксидації ліпідів у сироватці крові статевозрілих самок та самців контрольних підгруп встановлено більш низькі значення в самок. Так, вміст ТБК-активних продуктів у самців перевищував аналогічний показник у самок на $24,6 \%(p<0,02)$. У гомогенаті тканини легень статеві відмінності при порівнянні показників ПОЛ контрольних щурів виявилися ще виразнішими. Вміст ТБК-активних продуктів у самців перевищував аналогічний показник у самок на 29,7 \% $(p<0,01)$.

Більший окисний стрес у щурів-самців контрольної підгрупи може бути зумовлений підвищеною генерацією активних фрорм кисню та/або зниженням активності антиоксидантів. У здорових умовах клітинне дихання в мітохондріях $€$ домінуючим джерелом активних фоорм кисню. Тому вищий рівень метаболізму в чоловіків, ніж у жінок, може сприяти зростанню рівня окисного стресу в чоловіків [17]. Враховуючи антиоксидну активність естрогенів, нижчі показники ПОЛ у самок можна пояснити більшою ємністю антиоксидної системи самок. Відомо, що багато гормонів володіє антиоксидними властивостями. Естрогени, будучи френольними сполуками, пригнічують вільнорадикальне окиснення ліпідів біологічних мембран і ліпопротеїнів; деякі метаболіти естрогенів здатні відновлювати токофероксильні радикали; естрадіол, як і токофрерол, проявляє синергізм з вітаміном С, посилюючи антиоксидну дію [18].

За умови "пасивного тютюнокуріння" встановлено виражене зростання вмісту ТБК-активних продуктів як у сироватці крові, так і в гомогенаті тканини легень. У щурів-самців він достовірно збільшився у 3,3 та 4,2 раза відповідно, а в щурів-самок - у 3,9 і 5,2 раза.

Так само більший вміст ТБК-активних продуктів було виявлено в курців порівняно 3 некурцями $[19,20]$. Нові докази взаємозв'язку системного окисного стресу з легеневими фрункціями знайдено при проведенні дослідження населення у штаті Нью-Йорк. Н. M. Ochs-Balcom та співавт. показали зворотну асоціацію ТБК-активних продуктів $з$ показниками спірометрії в чоловіків, але не в жінок, що свідчить про гендерні відмінності відносно окисного стресу до фрункції легень [21].

За даними О. Б. Пікаса [5], в сигаретному димі міститься близько 1900 компонентів, багато з яких $є$ окисними агентами. Вільні радикали генерують ПОЛ, у результаті чого утворюються ліпідні радикали, які реагують з киснем у аеробних клітинах, продукуючи пероксильний радикал. Цей радикал запускає реакційний ланцюг, через який поліненасичені жирні кислоти перетворюються на гідропероксиди ліпідів. Ліпідна пероксидація зумовлює диссрункцію мембран, інактивацію мембранних ділянок

Таблиця 1 - Показники пероксидного окиснення ліпідів у статевозрілих щурів за умови

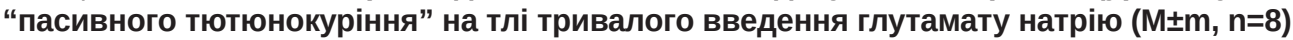

\begin{tabular}{|c|c|c|c|c|}
\hline Показник & Контроль & Тютюнокуріння & Глутамат натрію & $\begin{array}{l}\text { Тютюнокуріння+ } \\
\text { глутамат натрію }\end{array}$ \\
\hline \multicolumn{5}{|c|}{ Щури-самці } \\
\hline \multicolumn{5}{|c|}{ Сироватка крові } \\
\hline $\begin{array}{l}\text { ТБК-АП, } \\
\text { мкмоль/л }\end{array}$ & $3,24 \pm 0,19$ & $\begin{array}{c}10,79 \pm 0,33 \\
p_{1}<0,001\end{array}$ & $\begin{array}{l}5,06 \pm 0,26 \\
p_{1}<0,001\end{array}$ & $\begin{array}{c}15,83 \pm 0,65 \\
p_{1}<0,001 \\
p_{2}<0,001\end{array}$ \\
\hline \multicolumn{5}{|c|}{ Супернатант гомогенату легень } \\
\hline $\begin{array}{c}\text { ТБК-АП, } \\
\text { мкмоль/кг }\end{array}$ & $2,14 \pm 0,12$ & $\begin{array}{c}9,04 \pm 0,29 \\
p_{1}<0,001\end{array}$ & $\begin{array}{l}4,51 \pm 0,14 \\
p_{1}<0,001\end{array}$ & $\begin{array}{c}14,59 \pm 0,95 \\
p_{1}<0,001 \\
p_{2}<0,001\end{array}$ \\
\hline \multicolumn{5}{|c|}{ Щури-самки } \\
\hline \multicolumn{5}{|c|}{ Сироватка крові } \\
\hline $\begin{array}{l}\text { ТБК-АП, } \\
\text { мкмоль/л }\end{array}$ & $2,60 \pm 0,12$ & $\begin{array}{c}10,09 \pm 0,47 \\
p_{1}<0,001\end{array}$ & $\begin{array}{c}3,11 \pm 0,11 \\
p_{1}<0,01\end{array}$ & $\begin{array}{c}16,89 \pm 0,57 \\
p_{1}<0,001 \\
p_{2}<0,001 \\
\end{array}$ \\
\hline \multicolumn{5}{|c|}{ Супернатант гомогенату легень } \\
\hline $\begin{array}{l}\text { ТБК-АП, } \\
\text { мкмоль/кг }\end{array}$ & $1,65 \pm 0,07$ & $\begin{array}{c}8,67 \pm 0,27 \\
p_{1}<0,001\end{array}$ & $\begin{array}{c}2,54 \pm 0,14 \\
p_{1}<0,001\end{array}$ & $\begin{array}{c}14,69 \pm 0,53 \\
p_{1}<0,001 \\
p_{2}<0,001 \\
\end{array}$ \\
\hline
\end{tabular}

Примітки. Тут і в таблиці 2:

1. p $_{1}$ - достовірність відмінностей між контрольною та експериментальними підгрупами.

2. $\mathrm{p}_{2}$ - достовірність відмінностей між підгрупою тварин з тютюнокурінням і підгрупою щурів 3 тютюнокурінням на тлі введення глутамату натрію. 
рецепторів та фрерментів, підвищує проникність мембран [22].

Більш виражене зростання показників ТБК-активних продуктів у супернатанті гомогенату тканини легень порівняно із сироваткою крові в експериментальних тварин, імовірно, можна пояснити вищою інтенсивністю ліпідного обміну в легенях і тісною залежністю срункцій аерогематичного бар'єру від структури альвеолярних фоссроліпідів. Крім того, легеневу тканину, завдяки великій кількості альвеол і капілярно-альвеолярних контактів, розглядають як одну з найбільш обширних біологічних "мембран" в організмі, зовнішня поверхня якої постійно і безпосередньо контактує з киснем та іншими ініціаторами ПОЛ [23].

За умови тривалого введення глутамату натрію встановлено менш виражене зростання вмісту ТБК-активних продуктів як у сироватці крові, так і в гомогенаті тканини легень. У щурів-самців цей показник достовірно збільшився в 1,6 та 2,1 раза відповідно, а в щурів-самок - на 19,6 i $53,9 \%$.

У роботі О. Onyema та співавт. показано, що тривале вживання глутамату натрію призводить до окисного стресу та посилення вільнорадикального окиснення ліпідів і білків в організмі [24]. Л. П. Гордієнко та співавт. встановили, що за умов глутаматіндукованого ожиріння у слинних залозах піддослідних щурів достовірно підвищувався в 1,8 раза вміст ТБК-активних продуктів порівняно з контролем. При цьому в тканинах слинних залоз тварин активність каталази і супероксиддисмутази достовірно знижувалася в 1,5 й 1,8 раза щодо контрольних значень. Таким чином, спостерігали дисбаланс про- та антиоксидної систем слинних залоз щурів за умов глутаматіндукованого ожиріння [25].

У тварин, в яких моделювали "пасивне тютюнокуріння" та яким вводили глутамат натрію, встановлено найбільш виражене зростання вмісту ТБК-активних продуктів як у сироватці крові, так і в гомогенаті тканини легень. У щурів-самців цей показник достовірно підвищився в 4,9 та 6,8 раза відповідно, а в щурів-самок - у 6,5 і 8,9 раза.

При порівнянні показників пероксидації ліпідів у сироватці крові та гомогенаті тканини легень статевозрілих і статевонезрілих щурів контрольних підгруп встановлено нижчі значення у статевонезрілих тварин. Наші результати співзвучні з результатами досліджень О. С. Логашової та співавт., які виявили збільшення вмісту ТБК-активних продуктів з віком як у чоловіків, так і в жінок. Після 50 років спостерігали стабілізацію концентрації ТБК-АП. До 40 і після 50 років достовірних відмінностей серед жінок і чоловіків не виявлено, однак спостерігали тенденцію до збільшення вмісту ТБК-активних продуктів у сироватці крові чоловіків. Максимальні статеві відмінності у концентрації ТБК-активних продуктів відзначали у віці 40-49 років [26].

Аналізуючи показники вмісту ТБК-активних продуктів у сироватці крові та гомогенаті тканини легень статевонезрілих тварин, ми встановили їх достовірне переважання в усіх експериментальних підгрупах відносно статевозрілих щурів (табл. 2).

Таблиця 2 - Показники пероксидного окиснення ліпідів у статевонезрілих щурів за умови

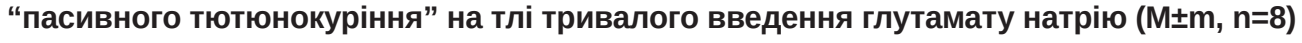

\begin{tabular}{|c|c|c|c|c|}
\hline Показник & Контроль & Тютюнокуріння & Глутамат натрію & $\begin{array}{l}\text { Тютюнокуріння+ } \\
\text { глутамат натрію }\end{array}$ \\
\hline \multicolumn{5}{|c|}{ Щури-самці } \\
\hline \multicolumn{5}{|c|}{ Сироватка крові } \\
\hline $\begin{array}{c}\text { ТБК-АП, } \\
\text { мкмоль/л }\end{array}$ & $1,85 \pm 0,13$ & $\begin{array}{l}6,46 \pm 0,23 \\
p_{1}<0,001\end{array}$ & $\begin{array}{c}3,88 \pm 0,19 \\
p_{1}<0,001\end{array}$ & $\begin{array}{c}11,39 \pm 0,49 \\
p_{1}<0,001 \\
p_{2}<0,001\end{array}$ \\
\hline \multicolumn{5}{|c|}{ Супернатант гомогенату легень } \\
\hline $\begin{array}{c}\text { ТБК-АП, } \\
\text { мкмоль/кг }\end{array}$ & $1,22 \pm 0,06$ & $\begin{array}{l}6,07 \pm 0,17 \\
p_{1}<0,001\end{array}$ & $\begin{array}{c}2,96 \pm 0,19 \\
p_{1}<0,001\end{array}$ & $\begin{array}{c}10,39 \pm 0,32 \\
p_{1}<0,001 \\
p_{2}<0,001\end{array}$ \\
\hline \multicolumn{5}{|c|}{ Щури-самки } \\
\hline \multicolumn{5}{|c|}{ Сироватка крові } \\
\hline $\begin{array}{c}\text { ТБК-АП, } \\
\text { мкмоль/л }\end{array}$ & $1,67 \pm 0,14$ & $\begin{array}{l}7,63 \pm 0,24 \\
p_{1}<0,001\end{array}$ & $\begin{array}{c}2,61 \pm 0,14 \\
p_{1}<0,001\end{array}$ & $\begin{array}{c}13,78 \pm 0,53 \\
p_{1}<0,001 \\
p_{2}<0,001\end{array}$ \\
\hline \multicolumn{5}{|c|}{ Супернатант гомогенату легень } \\
\hline $\begin{array}{c}\text { ТБК-АП, } \\
\text { мкмоль/кг }\end{array}$ & $1,19 \pm 0,07$ & $\begin{array}{c}8,92 \pm 0,42 \\
p_{1}<0,001\end{array}$ & $\begin{array}{c}2,15 \pm 0,16 \\
p_{1}<0,001\end{array}$ & $\begin{array}{c}16,37 \pm 0,43 \\
p_{1}<0,001 \\
p_{2}<0,001 \\
\end{array}$ \\
\hline
\end{tabular}


ВИСНОВКИ. 1. За умови "пасивного тютюнокуріння" спостерігають інтенсифрікацію пероксидного окиснення ліпідів (підвищення вмісту ТБК-активних продуктів) у крові та тканині легень, більш виражену при “пасивному тютюнокурінні” на тлі введення глутамату натрію.

\section{СПИСОК ЛІТЕРАТУРИ}

1. Current cigarette smoking among adults - United States, 2005-2015 / A. Jamal, B. A. King, L. J. Neff [et al.] // Morbidity and Mortality Weekly Report. - 2016. 65. - P. 1205-1211.

2. Clinical effects of cigarette smoking: epidemiologic impact and review of pharmacotherapy options / I. O. Onor, D. L. Stirling, S. R. Williams [et al.] // International Journal of Environmental Research and Public Health. $-2017 .-14 .-1147$ p.

3. Бахарєв В. С. Шкідливі звички як чинник фрормування екологічної небезпеки імпактного рівня / В. С. Бахарєв, О. Л. Корцова // Екологічна безпека. 2009. - № 1 (5). - С. 68-72.

4. Тяжка О. В. Пасивне куріння дітей раннього віку / О. В. Тяжка, Т. О. Ванханова // Медицина транспорту України. - 2012. - № 1. - С. 93.

5. Пікас О. Б. Куріння цигарок серед населення та його роль у розвитку захворювань / О. Б. Пікас // Вісн. проблем біології і медицини. - 2016. - 1, № 1 (126). - C. 48-52.

6. Контроль над тютюном в Україні. Другий Національний звіт. - К.: МОЗ України, ДУ "Український інститут стратегічних досліджень МОЗ України”, 2014. $128 \mathrm{c}$.

7. Бельтюкова С. В. Определение глутамата натрия методом тонкослойной хроматографии с люминесцентным детектированием / С. В. Бельтюкова, Е. В. Малинка // Вісн. Одес. нац. ун-ту. Серія “Хімія”. 2016. - 21, вип. 1 (57). - С. 50-58.

8. Бевзо В.В.Дослідження токсодинаміки глутамату натрію на організм щурів за умов тривалого його введення / В.В.Бевзо // Клініч. та експерим. патологія. - 2016. - 15, № 2 (56), ч. 2. - С. 13-16.

9. Review of alleged reactions to monosodium glutamate and outcome of a multicenter doubleblind placebo-controlled study / R. Geha, A. Beiser, C. Ren [et al.] // Journal of Nutritional. - 2000. - 130. - P. 1058-1062.

10. Фалалєєва Т. М. Вплив тривалого введення глутамату натрію на структурно-срункціональний стан шлунка у щурів / Т. М. Фалалєєва, В. М. Кухарський, Т. В. Берегова // Фізіол. журн. - 2010. - 56, № 2. C. 201.

11. Бішко О. І. Вміст первинних і вторинних продуктів ліпопероксидації у тканинах щура за дії гістаміну та гіпохлориту натрію / О. І. Бішко, Н.П.Гарасим, Д. І. Санагурський // Біологічні Студії/Studia Biologica. 2014. - 8, № 2. - С. 75-90.

12. Соломина А. С. Влияние афробазола на генетическую и репродуктивную токсичность табачного дыма у крыс : дисс. ... канд. биол. наук : 14.03 .06 / Соломина Анна Сергеевна. - М., 2011. - 139 с.
2. При статевому зіставленні змін показників системи пероксидного окиснення ліпідів виявлено їх достовірне переважання в щурів-самок.

3. При віковому зіставленні змін показників системи пероксидного окиснення ліпідів встановлено їх достовірне переважання у статевонезрілих тварин.

13. Лизурчик Л. В. Влияние табачного дыма на содержание токсичных элементов в организме крыс / Л. В. Лизурчик, Е. В. Шейда // Вестн. ОГУ. - 2014. № 6 (167). - С. 71-74.

14. Влияние глипролинов на структурно-срункциональное состояние слизистой оболочки желудка и массу тела крыс в условиях длительного введения глутамата натрия / Т. М. Фалалеева, Г. Е. Самонина, Т. В. Береговая [и др.] // Фізика живого. - 2010. - 18, № 1. - С. 154-159.

15. European convention for the protection of vertebrate animals used for experimental and other scientific purposes. - Council of Europe. Strasbourg. 1986. - № 123. - 52 p.

16. Коробейникова Э. Н. Модификация определения продуктов ПОЛ в реакции с тиобарбитуровой кислотой / Э. Н. Коробейникова // Лаб. дело. - 1989. № 7. - C. 8-10.

17. Greater oxidative stress in healthy young men compared with premenopausal / T. Ide, H. Tsutsui, N. Ohashi [et al.] // Journal of Arteriosclerosis, Thrombosis, and Vascular Biology. - 2002. - 22 (3). - P. 438-442.

18. Мажитова М. В. Возрастные и половые особенности свободнорадикальных процессов и антиоксидантной защиты плазмы крови белых крыс / М. В. Мажитова, Д. Д. Теплый // Естественные науки. 2010. - № 1 (30). - C. 79-85.

19. Systemic effects of smoking / D. G. Yanbaeva, M. A. Dentener, E. C. Creutzberg [et al.] // Chest. -2007. 131 (5). - P. 1557-1566.

20. Orhan H. Erythrocyte antioxidant defence response against cigarette smoking in humans: the glutathione S-transferase vulnerability / H. Orhan, C. T. Evelo, G. Sahin // Journal of Biochemical and Molecular Toxicology. - 2005. - 19. - P. 226-233.

21. Oxidative stress and pulmonary function in the general population / H. M. Ochs-Balcom, B. J. Grant, P. Muit [et al.] // American Journal of Epidemiology. 2005. - 162. - P. 1137-1145.

22. Murărescu E. D. Morphological changes positive correlates with oxidative stress in COPD. Preliminary data of an experimental rat model - study and literature review / E. D. Murărescu, R. lancu, M. S. Mihailovici // Romanian Journal of Morphology and Embryology. 2007. - 48 (1). - P. 59-65.

23. Нестеров Ю. В. Перекисное окисление липидов в легочной ткани крыс разного возраста в условиях острого эмоционально-болевого стресса/Ю. В. Нестеров // Вестн. ОГУ. - 2003. - № 6. - С. 152-155.

24. Onyema $\mathrm{O}$. Monosodium glutamate induces oxidative stress and affects glucose metabolism in the 
kidney of rats / O. O. Onyema, C. S. Alisi, A. P. Ihetuge // International Journal of Biochemistry Research \& Review. - 2012. - 2, № 1. - P. 1-11.

25. Розвиток оксидативного стресу в тканинах слинних залоз щурів за умов глутаматіндукованого ожиріння / Л. П. Гордієнко, Т. В. Берегова, К. С. Непо- рада, Т. М. Фалалєєва // Фізіол. журн. - 2014. - 60, № 4. - C. 105-107.

26. Логашова О. С. Содержание малонового диальдегида и церулоплазмина в сыворотке крови мужчин и женщин разного возраста / О. С. Логашова, И. В. Лопатин, Т. Г Анищенко // Успехи современного естествознания. - 2004. - № 10. - С. 39.

\section{REFERENCES}

1. Jamal, A., King, B.A., Neff, L.J., Whitmill, J., Babb, S.D. \& Graffunder, C.M. (2016). Current cigarette smoking among adults - United States, 2005-2015. Morbidity and Mortality Weekly Report, 65, 1205-1211.

2. Onor, I.O., Stirling, D.L., Williams, S.R., Bediako, D., Borghol, A., Harris, M.B., Darensburg, ... Sarpong, D.F. (2017). Clinical effects of cigarette smoking: epidemiologic impact and review of pharmacotherapy options. International Journal of Environmental Research and Public Health, 14, 1147.

3. Bakhariev, V.S. \& Kortsova O.L. (2009). Shkidlyvi zvychky yak chynnyk formuvannia ekolohichnoi nebezpeky impaktnoho rivnia [Harmful habits as a factor in the formation of the ecological danger of the impact level]. Ekolohichna bezpeka - Ecological Safety, 1(5), 68-72 [in Ukrainian].

4. Tiazhka, O.V. \& Vankhanova, T.O. (2012). Pasyvne kurinnia ditei rannoho viku [Passive smoking for young children]. Medytsyna transportu Ukrainy - Medicine of Transport of Ukraine, 1, 93 [in Ukrainian].

5. Pikas, O.B. (2016). Kurinnia tsyharok sered naselennia ta yoho rol u rozvytku zakhvoriuvan [Smoking of cigarettes among the population and its role in the development of diseases]. Visnyk problem biolohii $i$ medytsyny - Journal of Problems of Biology and Medicine, 1, 1(126) [in Ukrainian].

6. Kontrol nad tiutiunom v Ukraini. Druhyi Natsionalnyi zvit [Tobacco Control in Ukraine. Second National Report]. (2014). Kyiv: MOZ Ukrainy, DU «Ukrainskyi instytut stratehichnykh doslidzhen MOZ Ukrainy» [in Ukrainian].

7. Beltiukova, S.V. \& Malinka, E.V. (2016). Opredelenie glutamata natriya metodom tonkosloynou khromatografii $\mathrm{s}$ lyuminestsentnym detektirovaniem [Determination of sodium glutamate by thin layer chromatography with luminescent detection]. Visnyk Odeskoho natsionalnoho universytetu. Khimiia - Journal of Odesa National University. Chemistry, 21, 1(57) [in Russian].

8. Bevzo, V.V. (2016). Doslidzhennia toksodynamiky hlutamatu natriiu na orhanizm shchuriv za umov tryvaloho yoho vvedennia [Research toxicodynamics sodium glutamate in rats under prolonged its introduction]. Klinichna ta eksperementalna patolohiia - Journal of Clinical and Experimental Pathology, 2 (56), 13-16 [in Ukrainian].

9. Geha, R., Beiser, A. \& Ren, C. (2000). Review of alleged reactions to monosodium glutamate and outcome of a multicenter double blind placebo-controlled study. Journal of Nutritional, 130, 1058-1062.

10. Falalieieva, T.M., Kukharskyi, V.M. \& Berehova, T.V. (2010). Vplyv tryvaloho vvedennia hlutamatu natriiu na strukturno-funktsionalnyi stan shlunka u shchuriv [The impact of prolonged administration of sodium glutamate on the structural and functional state of the stomach in rats]. Fiziolohichnyi zhurnal - Journal of Physiology, 2 (56), 201 [in Ukrainian].

11. Bishko, O.I., Harasym, N.P. \& Sanahurskyi, D.I. (2014). Vmist pervynnykh i vtorynnykh produktiv lipoperoksydatsii u tkanynakh shchura za dii histaminu ta hipokhlorytu natriiu [Content of primary and secondary lipoperoxidation products in rat tissues under the action of histamine and sodium hypochlorite]. Biolohichni Studii / Studia Biologica - Biological Studios / Studia Biologica, 8 (2), 75-90 [in Ukrainian].

12. Solomina, A.S. (2011). Vliyanie afobazola na geneticheskuyu i reproduktivnuyu toksichnost tabachnogo dyma u krys [The effect of afobazole on the genetic and reproductive toxicity of tobacco smoke in rats]. Candidate's thesis. Moscow: NII farmakologii imeni V. V. Zakusova RAMN [in Russian].

13. Lizurchik, L.V. \& Sheyda, E.V. (2014). Vliyanie tabachnogo dyma na soderzhanie toksichnykh elementov v organizme krys [Effect of tobacco smoke on the content of toxic elements in the body of rats]. Vestnik OGU Journal of the Orenburg State University, 6 (167), 71-74 [in Russian].

14. Falalyeyeva, T.M., Samonina, G.E., Beregovaya, T.V., Dzyubenko, N.V. \& Andryeyeva, L.A. (2010). Vliyanie gliprolinov na strukturno-funktsionalnoye sostoyanie slizistoy obolochki zheludka i massy tela krys v usloviyakh dlitelnogo vvedeniya glutamata natriya [The effect of glyprolines on the structural and functional state of the gastric mucosa and the body weight of rats under conditions of prolonged administration of sodium glutamate]. Fizyka zhyvoho - Journal of the Physics of the Living, 18 (1), 154-159 [in Russian].

15. Council of Europe (1986). European convention for the protection of vertebrate animals used for experimental and other scientific purposes. Strasbourg, 123, 52.

16. Korobeynikova, E.N. (1989). Modifikatsiya opredeleniya produktov POL v reaktsii s tiobarbiturovoy kislotoy [Modification of the determination of LPO products 
in reaction with thiobarbituric acid]. Laboratornoe delo Laboratory Work, 7, 8-10 [in Russian].

17. Ide, T., Tsutsui, H., Ohashi, N., Hayashidani, S., Suematsu, N., Tsuchihashi, M., ... Takeshita, A. (2002). Greater oxidative stress in healthy young men compared with premenopausal women. Journal of Arteriosclerosis, Thrombosis, and Vascular Biology, 22 (3), 438-442.

18. Mazhitova, M.V. \& Teplyi, D.D. (2010). Vozrastnye i polovye osobennosti svobodnoradikalnykh protsessov i antioksidantnoy zashchity plazmy krovi belykh krys [Age and sexual characteristics of free radical processes and antioxidant protection of blood plasma of white rats] Estestvennye nauki - Journal of Natural Sciences, 1 (30), 79-85 [in Russian].

19. Yanbaeva, D.G., Dentener, M.A., Creutzberg, E.C., Wesseling, G.E. \& Wouters, F.M. (2007). Systemic effects of smoking. Chest, 131 (5), 1557-1566.

20. Orhan, H., Evelo, C. T. \& Sahin, G. (2005). Erythrocyte antioxidant defence response against cigarette smoking in humans: the glutathione S-transferase vulnerability. Journal of Biochemical and Molecular Toxicology, 19, 226-233.

21. Ochs-Balcom, H.M., Grant, B.J. \& Muit P. (2005). Oxidative stress and pulmonary function in the general population. American Journal of Epidemiology, 162, 11371145.

22. Murărescu, E.D., lancu, R. \& Mihailovici, M.S. (2007). Morphological changes positive correlates with oxidative stress in COPD. Preliminary data of an experi- mental rat model - study and literature review. Romanian Journal of Morphology and Embryology, 48 (1), 59-65.

23. Nesterov, Yu.V. (2003). Perekisnoe okislenie lipidov $v$ legochnoy tkani krys raznogo vozrasta $v$ usloviyakh ostrogo emotsionalno-bolevogo stressa [Peroxide oxidation of lipids in the lung tissue of rats of different ages in conditions of acute emotional and painful stress]. Vestnik OGU - Journal of the Orenburg State University, 6, 152-155 [in Russian].

24. Onyema, O. O., Alisi, C. S., Ihetuge, A. P. (2012). Monosodium glutamate induces oxidative stress and affects glucose metabolism in the kidney of rats. International Journal of Biochemistry Research \& Review, 1 (2), 1-11.

25. Hordiienko, L.P., Berehova, T.V., Neporada, K.S. \& Falalieieva, T.M. (2014). Rozvytok oksydatyvnoho stresu v tkanynakh slynnykh zaloz shchuriv za umov hlutamatindukovanoho ozhyrinnia [Development of oxidative stress in tissues of the salivary glands of rats under glutamate induced obesity]. Fiziolohichnyi zhurnal - Journal of Physiology, 4 (60), 105-107 [in Ukrainian].

26. Logashova, O.S., Lopatin, I.V. \& Anishchenko, T.G. (2004). Soderzhanie malonovogo dialdegida i tseruloplazmina v syvorotke krovi muzhchin i zhenshchin raznogo vozrasta [The content of malonic dialdehyde and ceruloplasmin in the blood serum of men and women of different ages]. Uspekhi sovremennogo estestvoznaniya - Journal of Progress of Modern Natural Science, 10, 39 [in Russian].

А. В. Руцкая, И. Я. Криницкая, М. И. Марущак ТЕРНОПОЛЬСКИЙ ГОСУДАРСТВЕННЫЙ МЕДИЦИНСКИЙ УНИВЕРСИТЕТ ИМЕНИ И. Я. ГОРБАЧЕВСКОГО

\section{ПОКАЗАТЕЛИ СВОБОДНОРАДИКАЛЬНОГО ОКИСЛЕНИЯ У КРЫС В УСЛОВИЯХ “ПАССИВНОГО ТАБАКОКУРЕНИЯ” НА ФОНЕ ДЛИТЕЛЬНОГО ВВЕДЕНИЯ ГЛУТАМАТА НАТРИЯ В ПОЛОВОМ И ВОЗРАСТНОМ АСПЕКТАХ}

\section{Резюме}

Вступление. Значительная распространенность курения - глобальная проблема человечества, на решение которой направлены усилия многих ученых и специалистов. В то же время отличительной особенностью современных пищевых технологий является использование пищевых добавок. К самым распространенным пищевым добавкам как в Украине, так и в Европе относится глутамат натрия (E621), который не всегда безопасен для здоровья человека.

Цель исследования - изучить показатели свободнорадикального окисления в крови и ткани легких крыс в условиях “пассивного табакокурения" на фроне длительного введения глутамата натрия в половом и возрастном аспектах.

Методы исследования. Исследование проведено на 128 белых нелинейных половозрелых и неполовозрелых крысах обоего пола. Каждую группу животных было разделено на 4 подгруппы: 1-я - контроль; 2-я - крысы, у которых моделировали “пассивное табакокурение"; 3-я - крысы, которым вводили глутамат натрия; 4-я - крысы, у которых моделировали “пассивное табакокурение” на фроне введения глутамата натрия.

Результаты и обсуждение. В условиях “пассивного табакокурения” установлено выраженное возрастание содержания ТБК-активных продуктов как в сыворотке крови, так и в гомогенате ткани легких. 
У крыс-самцов он достоверно увеличился в 3,3 и 4,2 раза соответственно, а у крыс-самок - в 3,9 и 5,2 раза. При длительном введении глутамата натрия у самцов этот показатель достоверно повысился в 1,6 и 2,1 раза, а у самок - на 19,6 и 53,9%. У животных, у которых моделировали “пассивное табакокурение" и которым вводили глутамат натрия, установлено наиболее выраженное возрастание содержания ТБК-активных продуктов. У крыс-самцов данный показатель достоверно повысился в 4,9 и 6,8 раза, а у крыс-самок - в 6,5 и 8,9 раза.

Выводы. В условиях “пассивного табакокурения” наблюдают интенсификацию перекисного окисления липидов (повышение содержания ТБК-активных продуктов) в крови и ткани легких, более выраженную при “пассивном табакокурении" на фроне введения глутамата натрия. При половом сопоставлении изменений показателей системы перекисного окисления липидов выявлено их достоверное преобладание у крыс-самок, при возрастном - их достоверное преобладание у неполовозрелых животных.

КЛЮЧЕВЫЕ СЛОВА: табакокурение; глутамат натрия; свободнорадикальное окисление.

\author{
A. V. Rutska, I. Y. Krynytska, M. I. Marushchak
}

I. HORBACHEVSKY TERNOPIL STATE MEDICAL UNIVERSITY

\title{
INDICES OF FREE RADICAL OXIDATION IN RATS DURING “PASSIVE TOBACCO SMOKING” ON THE BASIS OF PROLONGED ADMINISTRATION OF MONOSODIUM GLUTAMATE IN THE SEX AND AGE ASPECTS
}

\section{Summary}

Introduction. The widespread prevalence of tobacco smoking is a global problem of humanity, the solution of which is directed at the efforts of many scientists and professionals. At the same time, the distinctive feature of modern food technologies is the use of nutritional supplements. One of the most common nutritional supplements in Ukraine and in Europe is glutamate sodium (E621), which is not always safe for human health.

The aim of the study - to investigate indices of free radical oxidation in rats during "passive tobacco smoking" on the basis of prolonged administration of monosodium glutamate in the sex and age aspects.

Research Methods. The study was conducted on 128 white, non-linear, sexually mature and sexually immature rats of both sexes. Each group of animals was divided into four subgroups: I - control; II - rats, which were modeled "passive tobacco smoking"; III - rats, which were given glutamate of sodium; IV - rats, which were modeled "passive tobacco smoking" against the background of the introduction of glutamate sodium.

Results and Discussion. Under the condition of "passive tobacco smoking" there is a pronounced increase in the TBA-active products (TBA-AP) content both in serum and in the lung tissue homogenate. In male-rats, this indicator has significantly increased by 3.3 and 4.2 times, respectively, and in female-rats - by 3.9 and 5.2 times, respectively. Given the prolonged administration of sodium glutamate in male-rats, this indicator significantly increased by 1.6 and 2.1 times, and in females-rats by $19.6 \%$ and $53.9 \%$ respectively. In animals, which were modeled "passive tobacco smoking" and administered glutamate sodium, the most pronounced increase in the content of TBA-AP was established. In male-rats, this indicator has increased significantly in 4.9 and 6.8 times, and in femalerats - by 6.5 and 8.9 times, respectively.

Conclusions. Under the condition of "passive tobacco smoking" intensification of peroxide oxidation of lipids (increase in the content of TBA-active products) in blood and lung tissue is observed, more pronounced under the condition of "passive tobacco smoking" against the background of the introduction of glutamate sodium. In the sexual comparison of changes in the system of lipid peroxidation, their reliable prevalence in female-rats was revealed. With the age-old comparison of changes in the system of lipid peroxidation, their reliable prevalence in immature animals has been established.

KEY WORDS: tobacco smoke; sodium glutamate; free radical oxidation.

Отримано 06.10.17

Адреса для листування: А. В. Руцька, Тернопільський державний медичний університет імені І. Я. Горбачевського, майдан Волі, 1 , Тернопіль, 46001, Україна, e-mail: nastya@tdmu.edu.ua. 